\title{
Influence of feeding on the development of bacterial gill disease in rainbow trout Oncorhynchus mykiss
}

\author{
D. D. MacPhee, V. E. Ostland, J. S. Lumsden, J. Derksen, H. W. Ferguson*
}

Fish Pathology Laboratory, Department of Pathology, Ontario Veterinary College, University of Guelph, Guelph, Ontario, Canada N1G 2W1

\begin{abstract}
Three trials were conducted to determine if feeding influenced the development of bacterial gill disease (BGD) in fingerling rainbow trout Oncorhynchus mykiss following bath exposure to Flavobacterium branchiophilum (LAB 4a). In each trial (Trial 1, $\mathrm{n}=70 \times 3$; Trial 2, $\mathrm{n}=140 \times 3$; Trial 3, $\mathrm{n}=250 \times 3$ ), the comparison groups (fed, unfed, negative controls) were held in similar conditions and (where applicable) fed prior to exposure to the pathogen. Severe clinical signs and high rates of mortality developed within $24 \mathrm{~h}$ in fish which were provided feed following the bath exposure. Cumulative mortalities ranged from 43 to $63 \%$ by $12 \mathrm{~d}$ post-exposure. Unfed fish demonstrated only mild and transient clinical signs of $B G D$, and cumulative mortalities of 0 to $2 \% 12 \mathrm{~d}$ post-exposure. In one trial, resumption of feeding $6 \mathrm{~d}$ post-exposure resulted in $26 \%$ cumulative mortality within $7 \mathrm{~d}$. Estimation of the quantity of $F$. branchiophilum antigen by enzyme-linked immunosorbent assay (ELISA) indicated that feeding facilitated colonization of the gill. The evaluation of water quality and direct observations suggest that the influence of feeding on BGD is linked to the consumption of feed by the fish, rather than to environmental changes arising from feeding. Alterations in the unstirred layer on the gill, secondary to feed consumption and waste excretion, may aid bacterial colonization.
\end{abstract}

KEY WORDS: Mucosal - Colonization - Respiration - Excretion

\section{INTRODUCTION}

Since first reported in Vermont, USA (Davis 1926), bacterial gill disease (BGD) has been recognized as a serious problem in aquaculture throughout North America (Snieszko 1981, Daoust \& Ferguson 1983, Bullock et al. 1991), as well as in Europe and Japan (Richards \& Roberts 1978, Farkas 1985, Heo et al. 1990). In Ontario, Canada, BGD is the most common disease of farmed fish and is regarded as a major limiting factor in salmonid production (Daoust \& Ferguson 1983, Speare \& Ferguson 1989).

Traditionally, infectious diseases were often considered the simple consequence of a pathogen colonizing a suitable host, with little importance attached to environmental influences on the agent or host. In a reversal of the stereotype, BGD was once considered to be a

- Addressee for correspondence disease caused primarily by the exposure of fish to poor environmental conditions. Colonization of the gill by filamentous bacteria was thought to be a nonspecific mixed infection secondary to environmental stressors, and not the primary mediator of the disease (Bullock 1972, Snieszko 1981). However, it is now established that a yellow pigmented filamentous bacterium, Flavobacterium branchiophilum (von Graevenitz 1990), is the etiologic agent of BGD (Wakabayashi et al. 1980, 1989, Farkas 1985, Ferguson et al. 1991, Ostland et al. 1994), and that the disease can be produced even under good water quality conditions (Ferguson et al. 1991). Nevertheless, the inevitable role of environmental factors in the development of the disease remains to be elucidated.

Isolation of the etiologic agent of BGD (Ferguson et al. 1991, Ostland et al. 1994) has permitted experimental reproduction of the disease. In this laboratory BGD has been repeatedly and consistently reproduced by $1 \mathrm{~h}$ 
bath exposure of rainbow trout Oncorhynchus mykiss to Flavobacterium branchiophilum (LAB 4a). In 2 trials however, bath exposure failed to produce BGD in any of the challenged fish (D. MacPhee unpubl. obs.). Those trials were similar to previous successful challenges, except that the fish were not fed following exposure to the bacteria. This observation prompted further experimentation aimed at determining whether feeding influences the development of BGD.

\section{MATERIALS AND METHODS}

General methodology. Three experimental trials were performed. Each trial consisted of 3 groups of rainbow trout fingerlings which differed only in nutrition and exposure status. One group in each trial, the 'fed' fish, were exposed to Flavobacterium branchiophilum and were fed daily following the challenge. A second group, the 'unfed' fish, were also exposed to F. branchiophilum but were not fed following the bath exposure. The third group, the negative controls, were not exposed to F. branchiophilum but were fed throughout each trial. In Trial 3, the unfed group was divided equally into 2 groups 6 d post-exposure. Regular feeding was then resumed for half of the fish. The duration of the trials was 13 to $14 \mathrm{~d}$, not including the acclimation period of 4 to $7 \mathrm{~d}$.

Fish. Rainbow trout fingerlings were raised in this laboratory from eyed eggs received from a local breeder. In all 3 trials the fish used were from the same genetic pool. In each trial, all fish came from the same population (i.e. rearing trough). Prior to stocking the experimental tanks, a sample of the source population was examined by gill whole mounts and histopathology in order to confirm the absence of morphologic lesions or filamentous bacteria on the gill. The fish were hand graded to ensure uniformity of size. The mean individual weights and number of fish used were: Trial 1: $4.0 \mathrm{~g}, \mathrm{n}=70$ fish per tank; Trial 2: $4.1 \mathrm{~g}, \mathrm{n}$ $=140$ fish per tank; Trial 3: $3.1 \mathrm{~g}, \mathrm{n}=250$ fish per tank.

Tank set-up. In each trial fish were held in identical tanks supplied with water from a common 651 header tank. The header tank was supplied with aerated well water in constant overflow. The header tank ensured uniform water pressure to each holding tank and similar inflow water quality among tanks. Tank volumes were $4 \mathrm{l}$ in Trial 1,8 1 in Trial 2, and 161 in Trial 3. The tanks were graduated in 1 lincrements to permit ready calibration of volume as the biomass decreased due to sampling or mortality. Water flow to each tank was set at 1 turnover $\mathrm{h}^{-1}$. As the tank population was reduced by sampling or mortality, the water volume was decreased in order to keep the stocking density constant, and the flow rate to each tank was adjusted to keep the turnover time constant at $1 \mathrm{~h}$. The tanks were stocked $\left(45 \mathrm{~g} \mathrm{l}^{-1}\right)$ with fish 4 to $7 \mathrm{~d}$ prior to the challenge to allow the fish to acclimate. Thereafter, the weight of any withdrawals, and the remaining biomass, were recorded. The tank water volume, flow rate and ration weight were adjusted daily on the basis of the biomass/volume remaining.

Preparation of bacteria and bath exposure. The LAB 4 a strain of Flavobacterium branchiophilum (Ostland et al. 1994) was used for all bath exposures. A $48 \mathrm{~h}$ cytophaga broth culture of $F$. branchiophilum was prepared for each challenge, and bath exposure was performed as previously described (MacPhee et al. 1995). The water supply to each tank was turned off, but the aeration was maintained. In Trials 1,2 and 3 the tanks of fed and unfed fish received 250,125 or $50 \mathrm{ml} \mathrm{l}^{-1}$ tank volume, respectively, of the $48 \mathrm{~h}$ broth culture of $F$. branchiophilum. The resulting concentrations of bacteria were approximately $2.75 \times 10^{6}, 1.25 \times 10^{6}$ and $6.6 \times 10^{5}$ colony forming units (CFU) $\mathrm{ml}^{-1}$, respectively. The negative control tank received an equal volume of sterile cytophaga broth. After $1 \mathrm{~h}$ water flow was restored to all tanks.

Feeding. A ration of a commercial trout starter diet was delivered on the basis of the total biomass present. The total daily ration was divided into 3 to 5 feedings each day. During the acclimation period all tanks were fed at a level of $2 \%$ of the total body weight (bw) daily. Following the bath exposure the fed tank received 0.25 to $1.0 \%$ bw daily, depending on the feeding response of the fish. The unfed fish received no feed after the bath exposure. The control group was fed at a level of $2 \%$ bw daily for the duration of the trial. The 'resumedfeeding' tank in Trial 3 was provided with $2 \%$ bw daily ration, starting on Day 6 post-exposure.

Water quality. Daily records were kept on water temperature, dissolved oxygen (DO), pH and total ammonia for each tank (except that ammonia was not measured in the first trial). DO was determined using the azide modification for the Winkler Method, and total ammonia nitrogen using the Nessler Method. Both tests were included in the Hach DR-EL/4 test kit (Hach Chemical Company, Loveland, CO, USA). The pH was determined using an Accumet pH Meter 915 (Fisher Scientific, Ottawa, Canada).

Mortality data. The number of deaths in each tank was recorded daily and expressed as cumulative percent mortality (CPM). CPM was calculated using the equation: $C P M=$ [total mortalities $/$ (initial population at risk $-1 / 2$ withdrawals) $] \times 100$ (Martin et al. 1987). In this case the 'initial population at risk' was the number of fish present at the start of the bath exposure challenge. The 'withdrawals' were all fish removed for an event other than the event of interest over the duration of the trial. 
ELISA quantitation of Flavobacterium branchiophilum on gill. In Trial 3, gill tissues were collected for enzyme-linked immunosorbent assay (ELISA) estimation of the amount of $F$. branchiophilum antigen. All treatment groups were sampled $1 \mathrm{~h}$ prior to exposure and $1 \mathrm{~h}, 12 \mathrm{~h}, 48 \mathrm{~h}, 60 \mathrm{~h}, 4 \mathrm{~d}, 5 \mathrm{~d}, 6 \mathrm{~d}, 7 \mathrm{~d}, 8 \mathrm{~d}, 9 \mathrm{~d}$, and $12 \mathrm{~d}$ post-exposure. The fed fish were also sampled at $24 \mathrm{~h}$ and $36 \mathrm{~h}$ post-exposure. Sampling of the resumedfeeding fish did not begin until Day 7 , following the split of the group of unfed fish. Tissue collection, processing and the ELISA were performed using the methods previously described (MacPhee et al. 1995). The positive cut-off value for the $F$. branchiophilum ELISA was previously established at twice the mean absorbance of normal gill samples (MacPhee et al. 1995). A homologous quantitative reference curve was included in each assay, and the absorbance $(405 \mathrm{~nm})$ of each test sample was interpreted as proportional to the quantity of $F$. branchiophilum antigen present in the crude gill extract (MacPhee et al. 1995).

Histopathology. Tissues were collected for histopathology in Trials 2 and 3. In Trial 2, 7 fish were sampled from each tank prior to the bath exposure and $1 \mathrm{~h}$, $24 \mathrm{~h}, 48 \mathrm{~h}, 96 \mathrm{~h}$ and $7 \mathrm{~d}$ post-exposure. In Trial 3, the fish sampled for the ELISA were fixed for histopathology by removing the remaining operculum, opening the body cavity and placing each fish in phosphatebuffered $10 \%$ formalin. At a later date samples were selected for examination. The second right gill arch was removed from each fixed fish. They were placed in a cassette, dehydrated, embedded in paraffin wax, sectioned at $6 \mu \mathrm{m}$ and stained with hematoxylin and eosin (Thompson \& Hunt 1966).

Statistical evaluation. A 2-way analysis of variance (ANOVA) was used to test the null hypothesis that ELISA optical density did not differ significantly with tank treatment or sampling time. For each treatment group, the Duncan Multiple Range Analysis determined which sampling occasions yielded significantly different mean absorbances $(\alpha=0.05)$. Similarly, the Duncan Multiple Range Test was used to test for significant differences among treatment groups at each sample time $(\alpha=0.05)$. All statistical analyses were accomplished using the tests of SAS programs (SAS Institute, Cary, NC, USA).

\section{RESULTS}

\section{Clinical signs and mortality}

The clinical signs and mortality pattern were similar among the 3 trials. During the 4 to $7 \mathrm{~d}$ acclimation period, there were no deaths in any tanks. All fish fed well and no clinical signs of disease were evident. Within 12 to $24 \mathrm{~h}$ of exposure to Flavobacterium branchiophilum, both the fed and unfed fish showed moderate signs of respiratory disease including flared opercula, increased respiratory rate, hanging near the water surface and reduced fright response. The fed fish became progressively worse, and by $48 \mathrm{~h}$ postexposure exhibited marked to severe signs of $B G D$. The onset of clinical disease and mortalities varied slightly from trial to trial, but each produced the same overall pattern. In Trial 1 , the cumulative mortality of fed fish peaked on Day 9 at $63 \%$. In Trials 2 and 3 , the cumulative mortality also peaked on Day 9 at $59 \%$ and $43 \%$, respectively (Table 1 ).

In contrast to the fed fish, the unfed fish steadily improved following the expression of moderate clinical signs 12 to $24 \mathrm{~h}$ post-exposure, and were generally normal by $72 \mathrm{~h}$ post-exposure. Furthermore, there

Table 1. Oncorhynchus mykiss. Summary of the cumulative percent mortality in each treatment group in Trials 1 to 3. In Trial 3, the unfed group was split at $6 \mathrm{~d}$ following exposure and half of the fish were returned to feeding

\begin{tabular}{|c|c|c|c|c|c|c|c|c|c|c|c|c|c|c|c|}
\hline & & \multicolumn{14}{|c|}{ Day post-exposure } \\
\hline & & 0 & 1 & 2 & 3 & 4 & 5 & 6 & 7 & 8 & 9 & 10 & 11 & 12 & 13 \\
\hline \multirow[t]{3}{*}{ Trial $1^{a}$} & Fed & 0 & 2 & 5 & 19 & 46 & 51 & 52 & 52 & 57 & 63 & 63 & 63 & 63 & \\
\hline & Unfed & 0 & 0 & 0 & 0 & 0 & 0 & 0 & 0 & 0 & 0 & 0 & 0 & 0 & \\
\hline & Controls & 0 & 0 & 0 & 0 & 0 & 0 & 0 & 0 & 0 & 0 & 0 & 0 & 0 & \\
\hline \multirow{3}{*}{ Trial $2^{b}$} & Fed & 0 & 4 & 22 & 47 & 52 & 53 & 54 & 56 & 57 & 59 & 59 & 59 & 59 & \\
\hline & Unfed & 0 & 0 & 0 & 1 & 1 & 2 & 2 & 2 & 2 & 2 & 2 & 2 & 2 & \\
\hline & Controls & 0 & 0 & 0 & 0 & 0 & 0 & 0 & 0 & 0 & 0 & 0 & 0 & 0 & \\
\hline \multirow[t]{4}{*}{ Trial $3^{c}$} & Fed & 0 & 0 & 3 & 15 & 24 & 32 & 38 & 40 & 40 & 43 & 43 & 43 & 43 & 43 \\
\hline & Unfed & 0 & 0 & 0 & 0 & 0 & 0 & 0 & 0 & 0 & 0 & 0 & 0 & 0 & 0 \\
\hline & Controls & 0 & 0 & 0 & 1 & 1 & 1 & 1 & 1 & 1 & 1 & 1 & 1 & 2 & 4 \\
\hline & Resumed-feeding & - & - & - & - & - & - & 0 & 0 & 0 & 3 & 3 & 7 & 11 & 26 \\
\hline
\end{tabular}


were very low levels of mortality in the unfed fish. In Trials 1 and 3, none of the unfed fish died. In Trial 2 there was $2 \%$ cumulative mortality in the unfed fish (Table 1). Resumption of feeding $6 \mathrm{~d}$ post-exposure during Trial 3 resulted in mortality within $3 \mathrm{~d}$ which reached high levels (26\% cumulative) within $7 \mathrm{~d}$.

There were no deaths in the control tanks in Trials 1 and 2. In Trial 3 fish in the control group developed clinical signs of BGD $12 \mathrm{~d}$ post-exposure. Whole mount examination of gills of moribund fish revealed filamentous organisms. The development of BGD in the negative control tank was attributed to the probable accidental introduction of Flavobacterium branchiophilum from an adjacent infected tank

\section{Histopathology}

Samples for histopathology were not coilected in Trial 1. In Trial 2, large numbers of filamentous bacteria were present on the lamellar and filamental epithelium of the fed and unfed fish immediately following exposure to Flavobacterium branchiophilum. In the fed fish, bacteria were abundant up to and including the last histopathology sample at $7 \mathrm{~d}$ post-exposure. Morphologic lesions included mild diffuse lamellar epithelial swelling $1 \mathrm{~h}$ post-exposure; moderate diffuse lamellar epithelial necrosis 24 to $48 \mathrm{~h}$ post-exposure; the appearance of significant lamellar apposition at $48 \mathrm{~h}$; and moderate epithelial hyperplasia and lamellar fusion $7 \mathrm{~d}$ post-exposure. The bacterial colonization of the gill of the unfed fish also persisted until the $7 \mathrm{~d}$ post-exposure sampling time. However, the infection appeared to be marginally less severe in the unfed fish than in the fed fish. The morphologic lesions in the unfed fish were also less severe than in the fed group, and progressed little past moderate diffuse lamellar epithelial swelling evident at $48 \mathrm{~h}$ post-challenge. The gills of negative control fish maintained a normal histologic appearance and showed no evidence of colonization by filamentous bacteria.

In Trial 3 the histopathology of the gills of the fed fish was similar to Trial 2. In the case of the unfed fish, large numbers of filamentous bacteria were evident on the gill until $72 \mathrm{~h}$ post-exposure, but were difficult to detect at later sampling times. Resumption of feeding was followed within $3 \mathrm{~d}$ by the presence of large numbers of filamentous organisms on the gill and morphologic lesions typical of BGD

\section{ELISA enumeration of Flavobacterium branchiophilum}

The results of the ELISA estimation of the quantity of Flavobacterium branchiophilum on the gills of fed, unfed, resumed-feeding and control groups in Trial 3 are presented in Table 2. A 2-way ANOVA of the ELISA absorbances, using the readings of each individual fish $(n=369)$, indicated that there was a significant treatment effect ( $\mathrm{p}<0.0001$ ), a significant time effect $(p<0.0001)$, and that the interaction between these 2 factors was significant $(p<0.0001)$

Table 2. Oncorhynchus mykiss. ELISA estimation of the amount of Flavobacterium branchiophilum antigen on the gills of fed unfed, resumed-feeding and negative control fish in Trial 3. Values are mean ELISA optical density (OD) (405 nm) of gill extracts $\pm \mathrm{SEM}_{\mathrm{i}} \mathrm{n}=9$ fish. The positive cut-off value for the $F$. branchiophilum ELISA was previously established at twice the mean absorbance of normal gill samples

\begin{tabular}{|c|c|c|c|c|}
\hline Time $^{a}$ & Fed & Unfed & Resumed-feeding ${ }^{b}$ & Control \\
\hline$-1 h$ & $0.106 \pm 0.028$ & $0.103 \pm 0.006$ & $-\quad-$ & $0.093 \pm 0.007$ \\
\hline $1 \mathrm{~h}$ & $0.463 \pm 0.064$ & $0.587 \pm 0.089$ & $-\quad-$ & $0.092 \pm 0.021$ \\
\hline $12 \mathrm{~h}$ & $0.997 \pm 0.067$ & $0.430 \pm 0.057$ & $-\quad-$ & $0.090 \pm 0.008$ \\
\hline $1 \mathrm{~d}$ & $1.168 \pm 0.028$ & nd & $-\quad-$ & nd \\
\hline $1.5 \mathrm{~d}$ & $1.248 \pm 0.016$ & nd & $-\quad-$ & nd \\
\hline $2 d$ & $1.315 \pm 0.022$ & $0.335 \pm 0.046$ & $-\quad-$ & $0.083 \pm 0.025$ \\
\hline $2.5 \mathrm{~d}$ & $1.145 \pm 0.054$ & $0.148 \pm 0.015$ & $-\quad-$ & $0.080 \pm 0.007$ \\
\hline $4 \mathrm{~d}$ & $1.248 \pm 0.013$ & $0.095 \pm 0.012$ & $-\quad-$ & $0.062 \pm 0.005$ \\
\hline $5 d$ & $1.203 \pm 0.044$ & $0.154 \pm 0.031$ & $-\quad-$ & $0.071 \pm 0.007$ \\
\hline $6 \mathrm{~d}$ & $1.172 \pm 0.037$ & $0.116 \pm 0.015$ & $0.116 \pm 0.015$ & $0.086 \pm 0.002$ \\
\hline $7 d$ & $1.284 \pm 0.026$ & $0.124 \pm 0.018$ & $0.213 \pm 0.017$ & $0.092 \pm 0.010$ \\
\hline $8 d$ & $1.408 \pm 0.042$ & $0.138 \pm 0.014$ & $0.178 \pm 0.035$ & $0.101 \pm 0.004$ \\
\hline $9 \mathrm{~d}$ & $1.071 \pm 0.046$ & $0.153 \pm 0.017$ & $0.510 \pm 0.073$ & $0.125 \pm 0.012$ \\
\hline $12 \mathrm{~d}$ & $0.707 \pm 0.077$ & $0.168 \pm 0.009$ & $1.416 \pm 0.015$ & nd $\quad-$ \\
\hline
\end{tabular}


Duncan's Multiple Range Analysis was used to determine significant differences between the mean ELISA absorbances among treatments at each sampling time, and among sampling times in each individual treatment (Table 3). Prior to the bath exposure challenge, there was no significant difference in the quantity of Flavobacterium branchiophilum antigen on the gills of the fed, unfed or control fish, and all were determined to be negative by the criteria of the ELISA (MacPhee et al. 1995). One hour following the challenge, bacterial antigen on the gills of fed and unfed fish was significantly higher than the pre-exposure level, significantly higher than the controls, and not significantly different from each other (Table 3).

The quantity of Flavobacterium branchiophilum antigen detected on the gills of the fed fish increased markedly $12 \mathrm{~h}$ following exposure and thereafter increased moderately, but significantly, during the 12 to $24 \mathrm{~h}$ post-exposure (Tables $2 \& 3$ ). However, the antigen quantity remained relatively constant for the next $7 \mathrm{~d}$.

In comparison, the antigen quantity on the gills of the unfed fish decreased moderately, but significantly, in the $12 \mathrm{~h}$ following exposure (Tables $2 \& 3$ ). For the next 36 h there was no significant change in the antigen level on the gill. However, $2 \mathrm{~d}$ post-exposure the

Table 3. Oncorhynchus mykiss. Significant differences, among groups and sampling times, in the detection of Flavobacterium branchiophilum antigen on the gills of fed unfed. resumed-feeding and negative control fish in Trial 3. Duncan's Multiple Range Analysis ( $\alpha=0.05$ ) was used to evaluate differences among the mean ELISA absorbance $(405 \mathrm{~nm})$ of gill extracts. Column 1 is a comparison among groups in each group (down the table). Column 2 is a comparison among groups at each sampling time (across the table). Samples with the same letter or symbol are not significantly different

\begin{tabular}{|c|c|c|c|c|c|c|c|c|}
\hline \multirow[t]{2}{*}{ Time $^{a}$} & \multicolumn{2}{|c|}{ Fed } & \multicolumn{2}{|c|}{ Unfed } & \multicolumn{2}{|c|}{ Resumed $^{\mathrm{b}}$} & \multicolumn{2}{|c|}{ Control } \\
\hline & 1 & 2 & 1 & 2 & 1 & 2 & 1 & 2 \\
\hline$-1 \mathrm{~h}$ & A & + & A & + & * & - & $A, B$ & + \\
\hline $1 \mathrm{~h}$ & B & ++ & B & ++ & * & * & $A, B, C$ & + \\
\hline $12 \mathrm{~h}$ & C & +++ & C & t+ & * & * & $A, B, C$ & + \\
\hline $1 \mathrm{~d}$ & $D, E$ & - & • & • & • & * & - & - \\
\hline $1.5 \mathrm{~d}$ & $D, F$ & - & • & - & $*$ & * & - & - \\
\hline $2 d$ & $F, G$ & $++t$ & $\mathrm{C}$ & t+ & * & * & $A, C$ & + \\
\hline $2.5 \mathrm{~d}$ & $D, E$ & ++ & A & + & * & • & C & + \\
\hline $4 \mathrm{~d}$ & $D, F$ & ++ & A & + & * & * & $\mathrm{C}$ & + \\
\hline $5 d$ & $D, E, F$ & ++ & A & + & $*$ & - & $\mathrm{C}$ & + \\
\hline $6 \mathrm{~d}$ & $D, E$ & ++ & A & + & * & $*$ & $A, B, C$ & + \\
\hline $7 \mathrm{~d}$ & $D, F, G$ & +++ & A & + & A. & ++ & $\mathrm{A}, \mathrm{B}, \mathrm{C}$ & + \\
\hline $8 \mathrm{~d}$ & G & ++ & A & + & A & + & $A, B, C$ & + \\
\hline $9 \mathrm{~d}$ & C,E & +++ & A & + & B & ++ & $B$ & + \\
\hline $12 \mathrm{~d}$ & $\mathrm{H}$ & +++ & A & + & C & ++ & - & - \\
\hline $\begin{array}{l}{ }^{\circ} \text { Time } \\
{ }^{b} \text { The } u \\
\text { and } \mathrm{f}\end{array}$ & $\begin{array}{l}\text { fter exp } \\
\text { afed tan } \\
\text { eding } w\end{array}$ & $\begin{array}{l}\text { posur } \\
\text { lk wa } \\
\text { vas re }\end{array}$ & of & $\begin{array}{l}\text { ranc } \\
\text { d eq }\end{array}$ & $\begin{array}{l}p h i \\
\text { ly } 6\end{array}$ & $\begin{array}{l}n \\
\text { pos } \\
\text { sh }\end{array}$ & xpos & \\
\hline
\end{tabular}

antigen quantity decreased significantly and approached the positive cut-off point. For the remainder of the experiment there was no significant change in antigen level in the unfed group, and it approximated the positive cut-off value of the test

At $6 \mathrm{~d}$ post-exposure the unfed group was split into 2 tanks, and feeding was resumed to half of the fish. Resumption of feeding resulted in a significant increase in bacterial antigen within $24 \mathrm{~h}$ (Tables $2 \& 3$ ), from a prefeeding level marginally below the positive cut-off value of the test. At that point the quantity of antigen was also significantly greater than the concurrent sample of unfed fish. The antigen levels continued to increase dramatically, and by $6 \mathrm{~d}$ following the resumption of feeding they had attained a level comparable to the peak observed in the fed fish.

The ELISA absorbances of the gills of fish in the control tank did not exceed the positive cut-off value for the assay, or change significantly from Days 1 to 9 post-exposure (Tables $2 \& 3$ ).

\section{Water quality}

Of the parameters measured (Table 4) only DO and ammonia showed appreciable differences among tanks. DO was comparable between the fed and unfed tanks (and the 'resumed-feeding' tank in Trial 3) (Table 1). The minimum level measured was not exceedingly low $\left(6.2 \mathrm{mg} \mathrm{l}^{-1}\right)$ and the mean concentrations (approximately $8 \mathrm{mg} \mathrm{l}^{-1}$ ) were quite adequate for salmonid aquaculture. The DO levels in the control tanks were somewhat lower, and approached the lower limit of $5 \mathrm{mg} \mathrm{l}^{-1}$ acceptable for salmonid aquaculture. The lower level of DO in the negative control was attributed to the higher feeding rate. The total ammonia was considerably higher in the fed and control tanks than in the unfed tank (Table 1). However, significant levels $\left(0.40 \mathrm{mg} \mathrm{l}^{-1}\right)$ were also detected in the tank containing unfed fish.

\section{DISCUSSION}

The importance of management and environmental factors in the development of BGD has long been proposed (Wolf 1945, Burrows 1964, Wood 1974, Snieszko 1981), although there is little experimental work to support the suggestion. One exception is the work of Bullock (1972) in which BGD was repeatedly induced in trout held under stressful conditions which produced crowding, low DO (4 to $5 \mathrm{mg} \mathrm{l}^{-1}$ ), high ammonia ( 0.5 to $1.5 \mathrm{mg} \mathrm{l}^{-1}$ ), and the accumulation of particulate matter (feed and feces). However, in a concurrent set of experiments (Bullock 1972), BGD could not be 
induced by stocking fish at the same densities and exposing them to chronic low DO (4 to $5 \mathrm{mg} \mathrm{l}^{-1}$ ), high ammonia ( 0.5 to $2.5 \mathrm{mg} \mathrm{l}^{-1}$ ), high levels of particulate matter, or a combination of low DO and high ammonia. The ambiguous results of the study led the author to conclude that the infection of gill tissue by BGD organisms probably occurred after trout were stressed by unfavourable environmental conditions, but that the specific conditions necessary for an outbreak were unknown and may be multifactorial (Bullock 1972). However, in the first set of experiments the trout were fed daily, while in the second group of experiments the fish were taken off feed (Bullock 1972). Therefore, $\mathrm{BGD}$ was only induced in the experiments in which fish were fed, but not in the experiments in which fish were not fed. Those results (Bullock 1972) are compatible with our finding that the presence or absence of feeding is critical to the development of BGD.

\section{Influence of water quality}

Since feeding influences a broad range of water quality parameters as well as the physiology of the fish, dissection of the relationship between feeding and BGD is not simple. However, the conclusion drawn from the ELISA data is that feeding facilitates Flavobacterium branchiophilum colonization of the gill. Bacterial colonization is defined as the attachment of bacteria to a specific site and subsequent multiplication at that site (Evans \& Evans 1990). Since the amount of antigen on the gill was similar in both the fed and the unfed fish immediately post-exposure, it is most likely that the influence of feeding was on F. branchiophilum multiplication following attachment.
In intensive aquaculture, diminished water quality is the most obvious consequence of feeding. Since eutrophication is expected to result in proliferation of yellow pigmented bacteria (Collins 1970, as cited by Snieszko 1974), one possibility is that feeding produces deteriorating water quality which encourages Flavobacterium branchiophilum multiplication on the gill Although that remains a possibility, our results suggest that water quality differences between tanks were not sufficient to explain the marked difference in mortality or F. branchiophilum colonization of the gill.

In our challenge trials, the tank set-up was carefully standardized to ensure that environmental conditions were constant over time and among tanks, the only variable being feeding (and attendant water quality alterations). The fish were kept in crowded conditions $\left(45 \mathrm{~g} \mathrm{l}^{-1}\right)$ with a low water flow rate (1 turnover $\mathrm{h}^{-1}$ ) which ensured that even unfed fish were not free of potential stressors (i.e. crowding). Furthermore, the dissolved oxygen, temperature and $\mathrm{pH}$ were comparable among tanks of fed and unfed fish (Table 4).

As expected, the ammonia concentrations (Table 4) and particulate matter accumulations (D. MacPhee pers. obs.) were greater in the tanks of fed fish than in tanks of unfed fish. However, the importance of ammonia is questionable. Bullock (1972) was unable to induce BGD in crowded, unfed fish exposed to sustained high levels of ammonia, even though fed fish in concurrent experiments repeatedly developed BGD. Furthermore, although the unfed fish in our experiment were exposed to lower levels of total ammonia than were the fed fish, significant amounts were nevertheless present throughout the trial (Table 4). It is unlikely that the 'all or nothing' mortality pattern observed in all 3 trials, and the marked differences

Table 4. Comparison of dissolved oxygen concentration (DO), water temperature, $\mathrm{pH}$ and total ammonia measurements among tanks in each trial

\begin{tabular}{|c|c|c|c|c|c|c|c|c|c|c|c|c|c|}
\hline & & \multicolumn{3}{|c|}{$\mathrm{DO}\left(\mathrm{mg} \mathrm{l}^{-1}\right)$} & \multicolumn{3}{|c|}{ Temperature $\left({ }^{\circ} \mathrm{C}\right)$} & \multicolumn{3}{|c|}{$\mathrm{pH}$} & \multicolumn{3}{|c|}{ Total ammonia $\left(\mathrm{mg} \mathrm{l}^{-1}\right)$} \\
\hline & & Min. & $\operatorname{Max}$ & Mean & Min. & Max. & Mean & Min. & Max. & Mean & Min. & Max. & Mean \\
\hline \multirow[t]{3}{*}{ Trial 1} & Fed & 6.5 & 9.0 & 8.0 & 12.0 & 13.5 & 12.6 & 7.86 & 8.35 & 8.26 & - & - & - \\
\hline & Unfed & 6.6 & 9.0 & 8.2 & 11.5 & 14.1 & 13.1 & 8.07 & 8.16 & 8.12 & - & - & - \\
\hline & Control & 5.9 & 7.9 & 6.7 & 11.8 & 13.7 & 12.8 & 7.95 & 8.16 & 8.04 & - & - & - \\
\hline \multirow[t]{3}{*}{ Trial 2} & Fed & 6.2 & 8.7 & 7.9 & 11.6 & 14.5 & 13.2 & 8.02 & 8.31 & 8.19 & 0.41 & 0.92 & 0.53 \\
\hline & Unfed & 6.4 & 9.0 & 8.1 & 12.2 & 13.3 & 12.7 & 8.00 & 8.37 & 8.21 & 0.20 & 0.92 & 0.39 \\
\hline & Control & 4.8 & 6.4 & 5.6 & 11.7 & 14.5 & 13.0 & 7.97 & 8.26 & 8.13 & 0.49 & 0.88 & 0.61 \\
\hline \multirow[t]{4}{*}{ Trial 3} & Fed & 7.0 & 9.0 & 7.9 & 13.5 & 14.0 & 13.9 & 8.05 & 8.29 & 8.15 & 0.37 & 0.96 & 0.57 \\
\hline & Unfed & 7.0 & 9.0 & 8.2 & 13.5 & 14.0 & 13.9 & 8.16 & 8.40 & 8.27 & 0.26 & 0.61 & 0.40 \\
\hline & Resumed-feeding $^{a}$ & 8.0 & 8.0 & 8.0 & 14.0 & 14.0 & 14.0 & 7.80 & 8.50 & 8.20 & 0.37 & 0.99 & 0.72 \\
\hline & Control & 5.0 & 7.0 & 6.2 & 13.5 & 14.0 & 13.9 & 7.93 & 8.24 & 8.12 & 0.44 & 0.98 & 0.66 \\
\hline
\end{tabular}


in the bacterial colonization of the gill, could be attributed to the difference in degree of ammonia present in the water. Rather, if ammonia were the critical determinant one would expect the bacterial colonization to be proportional to the ammonia concentration. Instead, bacterial numbers steadily declined in the unfed fish, while they rapidly increased on the gills of the fed fish.

\section{Host physiological changes}

An alternative explanation for the association between feeding and BGD development is that consumption of feed by the host produces physiologic changes which influence the development or expression of the disease. This idea is supported by the observation that in catheterized fish which are not able to capture feed poured into the water, stomach tube feeding is needed to produce BGD (P. Byrne \& D. MacPhee unpubl. obs.).

Feed consumption, digestion and metabolism place significant physiologic demands on the fish in general, and on the gill in particular. Feeding results in increased oxygen consumption, carbon dioxide excretion, and excretion of nitrogenous waste (Brett \& Zala 1975, Chakraborty et al. 1992) which occurs mainly in the form of ammonia via diffusion from the plasma, through the lamellar epithelial bilayer, and into the 'unstirred boundary layer' overlying the lamellar epithelium (Wright \& Wood 1985). The unstirred layer is comprised mainly of mucus and water but also accumulates cellular debris, enzymes, excretory products and other associated compounds. The active excretion of ammonia and urea following feed consumption and metabolism, and accumulation of these compounds in the unstirred layer, effectively creates a nutrient-rich zone on the epithelial surface. By providing nutrients for bacterial growth, feed consumption may directly promote multiplication of Flavobacterium branchiophilum on the gills, following initial attachment.

If pili are required for attachment of Flavobacterium branchiophilum to the lamellar epithelium, as seems likely (Ostland et al. 1994), an association between feeding and colonization becomes apparent. The charge interactions between bacteria and target cells are particularly important for adhesion, and most pili are negatively charged, with isoelectric points in the range 3.7 to 5.6 (Isaacson 1985). Therefore, mucosal surface pH can play an important role in attachment, and acidification of the unstirred layer of the gill, as is produced with increased carbon dioxide excretion (Randall \& Wright 1989) as a result of feeding, may produce an environment suitable for the function of $F$. branchiophilum colonization factors or adhesins.
Moreover, the presence of a specific substance in the unstirred layer, secondary to feed consumption and excretion, may promote the expression of a colonization factor antigen which may facilitate sustained bacterial attachment to the gill.

The presence of specific compounds in the gill boundary layer may also have an effect on movement of the pathogen to the epithelial surface (Isaacson 1985). For example, colonization of the intestine by Vibrio cholerae and Salmonella typhimurium is in part regulated by a bacterial chemotactic response to specific chemical attractants secreted by the tissue (Freter et al. 1981, Uhlman \& Jones 1982, Isaacson 1985). A variety of compounds actively excreted by the gill, secondary to feed consumption, digestion and absorption, may also function as chemotactic agents for Flavobacterium branchiophilum.

\section{Conclusion}

In summary, this work demonstrates that feeding has an important role in the experimental reproduction of BGD. The results also indicate that the effect of feeding is probably mediated, at least in part, by an influence on bacterial colonization of the gill. We propose that the influence of feeding is due to physiologic changes arising directly from feed consumption, rather than from general deterioration of water quality associated with feeding. However, the role of water quality or other environmental stressors requires further investigation. It is most likely that poor water quality provides optimal conditions for exposure of the fish to Flavobacterium branchiophilum, and that feeding produces physiologic changes in the host which facilitate bacterial colonization of the gill.

Acknowledgements. The Fish Pathology Laboratory receives most of its funding from the Ontario Ministry of Agriculture and Food. J.S.L. has a Medical Research Council Fellowship. Statistical evaluation was performed in consultation with Dr M. M. Shoukn, staff statistician of the Department of Population Medicine, University of Guelph.

\section{LITERATURE CITED}

Brett JR, Zala CA (1975) Daily pattern of nitrogen excretion and oxygen consumption of sockeye salmon (Oncorhynchus nerkal under controlled conditions. J Fish Res Bd Can 32:2479-2486

Bullock GL (1972) Studies on selected myxobacteria pathogenic for fishes and on bacterial gill disease in hatchery reared salmonids. US Fish Wildl Serv, Tech Pap 60:20-30

Bullock GL, Herman RL, Waggy C (1991) Hatchery efficacy trials with chloramine- $T$ for control of bacterial gill disease. J aquat Anim Health 3:48-50 
Burrows RE (1964) Effects of accumulated excretory products on hatchery-reared salmonids. US Fish Wildl Serv, Res Rep 66:1-12

Chakraborty SC, Ross LG, Ross B (1992) The effect of dietary protein level and ration level on the excretion of ammonia in common carp, Cyprinus carpio. Comp Biochem Physiol 103A:801-808

Collins VG (1970) Recent studies of bacterial pathogens of freshwater fish. Wat Treat Exam 19:3-31

Daoust PY, Ferguson HW (1983) Gill disease of cultured salmonids in Ontario. Can J comp Med 47:358-362

Davis HS (1926) A new gill disease of trout. Trans Am Fish Soc $56: 156-160$

Evans DJ, Evans DG (1990) Colonization factor antigens of human pathogens. In: Jann K, Jann B (eds) Bacterial adhesins. Current topics in microbiology and immunology 151. Springer Verlag, New York, p 129-145

Farkas J (1985) Filamentous Flavobacterium sp. isolated from fish with gill diseases in coldwater. Aquaculture 44:1-10

Ferguson HW, Ostland VE, Byrne P, Lumsden JS (1991) Experimental production of bacterial gill disease in trout by horizontal transmission and by bath challenge. $J$ aquat Anim Health 3.118-123

Freter R, Allweiss B, O'Brien PCM, Halstead SA, Macsai MS (1981) Role of chemotaxis in the association of mobile bacteria with intestinal mucosae $e_{i}$ in vitro studies. Infect Immunol 34:241-249

Heo GJ, Kasai K, Wakabayashi H (1990) Occurrence of Flavobacterium branchiophilum associated with bacterial gill disease at a trout hatchery. Fish Pathol 25:99-105

Isaacson RE (1985) Pilus adhesins. In: Savage DC, Fletcher $M$ (eds) Bacterial adhesion. Plenum Press, New York, p $307-338$

MacPhee DD, Ostland VE, Lumsden JS, Ferguson HW (1995) Development of an enzyme-linked immunosorbent assay (ELISA) to estimate the quantity of Flavobacterium branchiophilum on the gills of rainbow trout Oncorhynchus mykiss. Dis aquat Org 21:13-23

Martin SW, Meek AH, Willeberg P (1987) Veterinary epidemiology. Lowa State University Press, Ames

Responsible Subject Editor: O. Kinne, Oldendorf/Luhe, Germany
Ostland VE, Lumsden JS, MacPhee DD, Ferguson HW (1994) Characteristics of Flavobacterium branchiophilum, the cause of salmonid bacterial gill disease in Ontario, Canada. J aquat Anim Health 6:13-26

Randall, DJ, Wright, PA (1989) The interaction between carbon dioxide and ammonia excretion and water $\mathrm{pH}$ in fish Can J Zool 67:2936-2942

Richards RH, Roberts RJ (1978) The bacteriology of teleosts. In: Roberts RJ (ed) Fish pathology. Baillaire Tindall, London, p 183-204

Snieszko SF (1974) The effects of environmental stress on out breaks of infectious disease of fishes. J Fish Biol 6:197-208

Snieszko SF (1981) Bacterial gill disease of freshwater fishes. US Fish Wildl Serv, Fish Dis Leaf 62: 1-11

Speare DJ, Ferguson HW (1989) Clinical and pathological features of common gill diseases of cultured salmonids in Ontario. Can Vet J 30:882-887

Thompson SW, Hunt RD (1966) Selected histochemical and histopathological methods. Charles Thomas, Springfield

Uhlman D, Jones GW (1982) Chemotaxis as a factor in interactions between HeLa cells and Salmonella typhimurium. J gen Microbiol 128:415-417

von Graevenitz A (1990) Revised nomenclature of Campylobacter laridis, Enterobacter intermedium, and 'Flavobacterium branchiophila'. Int $\mathrm{J}$ syst Bact 40:211

Wakabayashi H, Egusa S, Fryer JL (1980) Characteristics of filamentous bacteria isolated from gill disease of salmonids. Can J Fish aquat Sci 37:1499-1504

Wakabayashi H, Huh GJ, Kimura N (1989) Flavobacterium branchiophila sp. nov., a causative agent of bacterial gill disease of freshwater fishes. Int J syst Bact 39:213-216

Wolf LE (1945) Dietary gill disease of trout. New York Cons Dept, Fish Res Bull 7:1-30

Wood JW (1974) Diseases of Pacific salmon: their prevention and treatment. Washington State Department of Fisheries, Olympia

Wright PA, Wood CM (1985) An analysis of branchial ammonia excretion in the freshwater rainbow trout: effects of environmental $\mathrm{pH}$ changes and sodium uptake blockade. $\mathrm{J} \exp$ Biol 114:329-353

Manuscript first received: December 12, 1993 Revised version accepted: February 24, 1995 